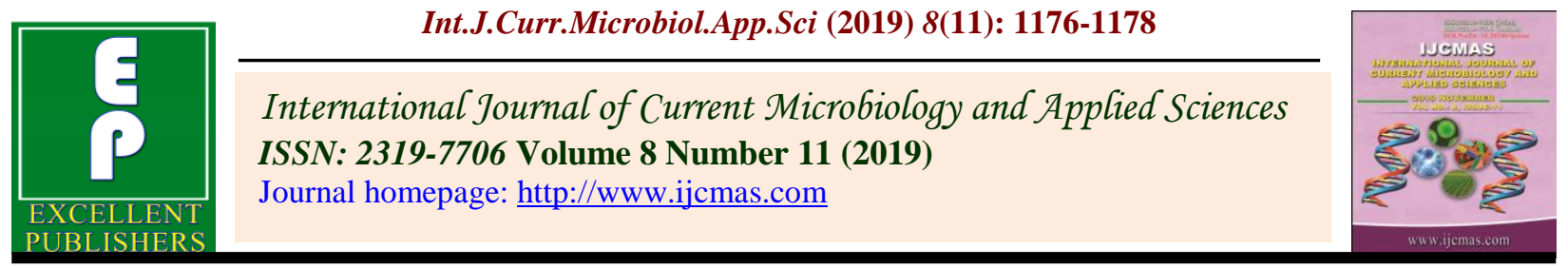

Short Communications

https://doi.org/10.20546/ijcmas.2019.811.138

\title{
Identification of Suitable Contingent Crops for Delayed Onset of Monsoon in Scarce Rainfall Zone of Andhra Pradesh, India
}

\author{
C. Prathyusha* and D. Sampath Kumar
}

Agricultural Research Station, AcharyaN.G.Ranga Agricultural University, Kadiri-515591, Ananthapur Dist, Andhra Pradesh, India

*Corresponding author

\section{A B S T R A C T}

Keywords

Castor, Foxtail millet, Pigeonpea, Greengram, Horsegram, Rainfall pattern, Amount, intensity

Article Info

Accepted:

10 October 2019 Available Online: 10 November 2019
A Field experiment was conducted during kharif, 2015 with twelve different crops (T1- Groundnut, T2- Castor, T3- Foxtail millet, T4Pigeonpea, T5-Greengram, T6- Horsegram, T7- Clusterbean, T8Fieldbean, T9-Cowpea, T10-Bajra, T11-Jowar, T12-Littlemillet) under delayed sowing conditions at Agricultural research Station, Kadiri. All the twelve crops were sown under two different dates of sowing, i.e., during September $1^{\text {st }} \mathrm{FN}$ and September $2^{\text {nd }} \mathrm{FN}$. Among the twelve crops evaluated for September sowings, groundnut resulted in negative returns. Highest groundnut pod equivalent yield was recorded with clusterbean for vegetable purpose in both the dates of sowing in September followed by foxtailmillet, littlemillet, horsegram and pearlmillet. While, considering the cost of cultivation, highest net returns were recorded with clusterbean (Rs. 26,537 and Rs.29,691/ha) followed by foxtailmillet (Rs. 14,887and Rs.9,899/ha) and littlemillet (Rs. 12,893 and Rs.7,712/ha).

\section{Introduction}

Rainfall is the most important but variable climatic parameter in suitable crop planning especially in the regions of rainfed agriculture. The rainfed agro-ecology is characterized as vulnerable for agricultural operations which revolve around moisture availability due to rainfall pattern, amount, intensity and its uses for crop production (Dekha and Nathm, 2000). Indrylands, occurance of drought is quite frequent at any stage of crop growth and length of growing period ranges from 75 to120days only. Vagaries in monsoon rains and breaks of varying duration are most common in Ananthapur district.

In Anantapur district, groundnut is being grown as a monocrop in 7.5 lakh hectares under rainfed conditions. The delayed onset of monsoon frequented with prolonged mid season droughts often results in crop failures. 
Moreover, every year delayed onset of monsoon also leads to 20000 to 65000 hectares of cultivated area left unsown in the district. The problem necessitated the identification of suitable contingent crops.

\section{Materials and Methods}

A field experiment was conducted during kharif, 2015 with twelve different crops(T1Groundnut, T2- Castor, T3- Foxtail millet, T4Pigeonpea, T5-Greengram, T6- Horsegram, T7- Clusterbean, T8- Fieldbean, T9-Cowpea, T10-Bajra, T11-Jowar, T12-Littlemillet) under delayed sowing conditions at Agricultural research Station, Kadiri. All the twelve crops were sown under two different dates of sowing, i.e., during September $1^{\text {st }} \mathrm{FN}$ and September $2^{\text {nd }} F N$.

\section{Results and Discussion}

Among the twelve crops evaluated for September sowings, groundnut resulted in negative returns. Highest groundnut pod equivalent yield was recorded with clusterbean for vegetable purpose (1043 and $1122 \mathrm{~kg} / \mathrm{ha}$ in Sep $1^{\text {st }}$ FN and Sep2 $2^{\text {nd }} F N$ respectively) in both the dates of sowing followed by foxtailmillet, littlemillet, horsegram and pearlmillet.

While, considering the cost of cultivation, highest net returns were recorded with clusterbean (Rs. 26,537 and Rs.29,691/hain Sep $1^{\text {st }}$ FN and Sep2 ${ }^{\text {nd }}$ FN respectively) followed by foxtailmillet (Rs. 14,887and Rs.9,899/ha) and littlemillet (Rs. 12,893 and Rs.7,712/ha) (Table 1 and Fig. 1).

Table.1 Yield and economics of different contingent crops under delayed sowing conditions

\begin{tabular}{|c|c|c|c|c|c|c|c|c|c|}
\hline \multirow[t]{2}{*}{ Treatment } & \multicolumn{2}{|c|}{$\begin{array}{c}\text { Groundnut } \\
\text { pod } \\
\text { equivalents } \\
\left(\mathrm{kg} \mathrm{ha}^{-1}\right)\end{array}$} & \multirow{2}{*}{$\begin{array}{c}\text { Cost of } \\
\text { cultivation } \\
\left(\mathrm{Rs} \mathrm{ha}^{-1}\right)\end{array}$} & \multicolumn{2}{|c|}{$\begin{array}{l}\text { Gross returns } \\
\quad\left(\text { Rs ha }^{-1}\right)\end{array}$} & \multicolumn{2}{|c|}{$\begin{array}{l}\text { Net returns } \\
\left(\text { Rs ha }^{-1}\right)\end{array}$} & \multicolumn{2}{|c|}{$\begin{array}{l}\text { Benefit cost } \\
\text { ratio }\end{array}$} \\
\hline & D1 & D2 & & D1 & D2 & D1 & D2 & D1 & D2 \\
\hline Groundnut & 604 & 430 & 25000 & 25368 & 18060 & 368 & -6940 & 1.01 & 0.72 \\
\hline Castor & 455 & 335 & 19400 & 18200 & 13400 & -1200 & -6000 & 0.94 & 0.69 \\
\hline $\begin{array}{c}\text { Foxtail } \\
\text { millet }\end{array}$ & 753 & 629 & 15250 & 30137 & 25149 & 14887 & 9899 & 1.98 & 1.65 \\
\hline Pigeonpea & 188 & 148 & 14500 & 18000 & 13620 & 3500 & -800 & 1.24 & 0.94 \\
\hline Greengram & 273 & 107 & 13250 & 17980 & 7018 & 4730 & -6232 & 1.35 & 0.52 \\
\hline Horsegram & 344 & 359 & 8650 & 13766 & 14366 & 5116 & 5716 & 1.59 & 1.66 \\
\hline Clusterbean & 1043 & 1122 & 15200 & 41737 & 44891 & 26537 & 29691 & 2.74 & 2.95 \\
\hline Fieldbean & 308 & 241 & 13250 & 12314 & 9657 & -936 & -3593 & 0.93 & 0.73 \\
\hline Cowpea & 388 & 186 & 13250 & 15514 & 7457 & 2264 & -5793 & 1.17 & 0.56 \\
\hline Bajra & 387 & 320 & 12500 & 15489 & 12790 & 2989 & 290 & 1.24 & 1.02 \\
\hline Jowar & 270 & 228 & 12500 & 10801 & 9114 & -1699 & -3386 & 0.86 & 0.73 \\
\hline Little millet & 629 & 499 & 12250 & 25143 & 19962 & 12893 & 7712 & 2.05 & 1.63 \\
\hline
\end{tabular}


Fig.1

Profitable contingent crops for delayed sowing situations
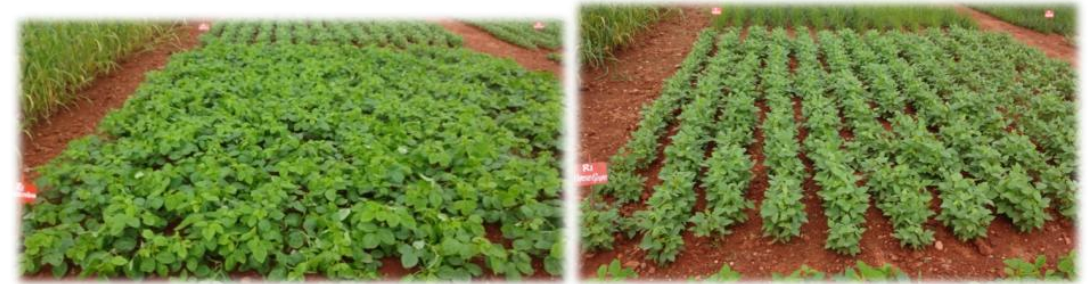

Cluster bean

Horse gram

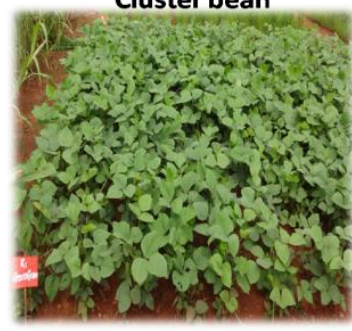

Green gram

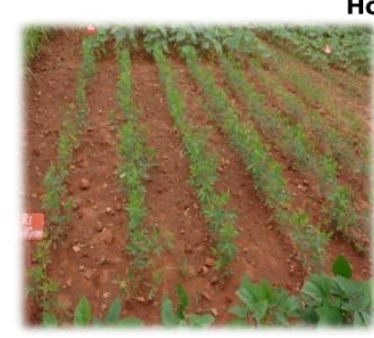

Redgram

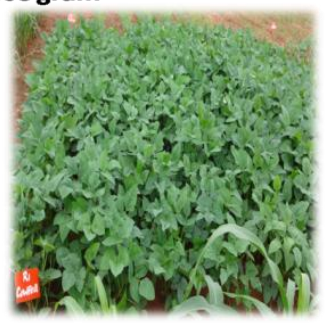

Cowpea

\section{References}

Deka, R.L. and Nath, K.K. (2000). Rainfall analysis for rainfed crop planning in the upper Brahmaputra valley zone of Assam. Journal of Agrometeorology., 2: 47-53.

\section{How to cite this article:}

Prathyusha, C. and Sampath Kumar, D. 2019. Identification of Suitable Contingent Crops for Delayed Onset of Monsoon in Scarce Rainfall Zone of Andhra Pradesh. Int.J.Curr.Microbiol.App.Sci. 8(11): 1176-1178. doi: https://doi.org/10.20546/ijcmas.2019.811.138 